ORIGINAL ARTICLE

\title{
Could nursery rhymes cause violent behaviour? A comparison with television viewing
}

\author{
P Davies, L Lee, A Fox, E Fox
}

Arch Dis Child 2004;89:1103-1105. doi: 10.1136/adc.2003.042499

See end of article for authors' affiliations

...................

Correspondence to: Dr P Davies, Emergency Department, Bristol Royal Hospital for Children, Bristol, UK; daviespatrick@ hotmail.com

Accepted 6 July 2004

\begin{abstract}
Aims: To assess the rates of violence in nursery rhymes compared to pre-watershed television viewing. Methods: Data regarding television viewing habits, and the amount of violence on British television, were obtained from Ofcom. A compilation of nursery rhymes was examined for episodes of violence by three of the researchers. Each nursery rhyme was analysed by number and type of episode. They were then recited to the fourth researcher whose reactions were scrutinised.

Results: There were 1045 violent scenes on pre-watershed television over two weeks, of which 61\% showed the act and the result; $51 \%$ of programmes contained violence. The 25 nursery rhymes had 20 episodes of violence, with $41 \%$ of rhymes being violent in some way; $30 \%$ mentioned the act and the result, with $50 \%$ only the act. Episodes of law breaking and animal abuse were also identified. Television has 4.8 violent scenes per hour and nursery rhymes have 52.2 violent scenes per hour. Analysis of the reactions of the fourth researcher were inconclusive.

Conclusions: Although we do not advocate exposure for anyone to violent scenes or stimuli, childhood violence is not a new phenomenon. Whether visual violence and imagined violence have the same effect is likely to depend on the age of the child and the effectiveness of the storyteller. Re-interpretation of the ancient problem of childhood and youth violence through modern eyes is difficult, and laying the blame solely on television viewing is simplistic and may divert attention from vastly more complex societal problems.
\end{abstract}

A pproximately $10 \%$ of violent crime in England and Wales is perpetrated by school age children. ${ }^{1}$ Although the rates of convictions in children have fallen, this is felt to be due to a change in policy by the courts to try to keep children out of custodial sentences. Self-reported crime rates in 14-17 year olds rose 14\% between 1992-93 and 1998-99. ${ }^{2}$ In Scotland in the 2002-03 year, 2267 incidents of violence against teachers by primary school pupils were reported, ${ }^{3}$ compared with 1376 in the 2000-01 year ${ }^{4}$ and 1791 in the 2001-02 year. ${ }^{5}$ Whether this increase is due to increased reporting or an increase in incidents is unknown.

Some high profile cases have been blamed on visual stimuli, from the Jamie Bulger murder to the case of the teenager who was convinced to attempt to murder his friend on the orders of a "secret agent". In both these cases, watching violent films was implicated in giving the children the knowledge and confidence to act.

As early as 1972, the US surgeon general wrote: "televised violence does have an adverse effect on certain members of our society". ${ }^{6}$ A recent major study ${ }^{7}$ showed a significant correlation between aggressive behaviour and the amount of time spent watching television in adolescence. Potential confounding factors including childhood neglect, previous aggressive behaviour, and neighbourhood violence were controlled for. A meta-analysis of all available studies in this field showed a correlation between exposure to media violence and aggression. ${ }^{8}$

Violence on television has also been increasing in nature and in scope. It is estimated that a child who watches two hours of cartoons per day will experience 10000 episodes of violence per year.9 The fashionable, TV based "sport" of wrestling is based around extreme levels of violence, including cross-gender fights. It has been associated with increased levels of violence on dates. ${ }^{10}$

However, television is not the only source of children's exposure to violence. The Harry Potter books contain examples of bullying, fighting, theft, subversion, lying, and murder. ${ }^{11}$ Once school age is reached, violence among peers is widespread and common, but even before this, maybe more insidious exposure has started. The authors were struck by the often violent nature of so-called "nursery" rhymes, which are recited to children from birth, throughout the world. Medical literature regarding violence in nursery rhymes is somewhat limited. However, it has been noted that that the care that follows head injuries to characters in nursery rhymes is generally lacking by modern standards. ${ }^{12}$ We wished to investigate, in view of the cited evidence regarding links between imagined or perceived violence and the actual acts, whether this danger could be present with traditional methods of child rearing.

Childhood educationalists broadly fit in to two classifications: the "traditionalists" and the "modernists". The traditionalists, conventionally headed by a mother-in-law, advocate the child rearing techniques which worked for them and for their parents. The modernists advocate the Teletubbies. It is natural that each group will blame the other for society's ills, especially the perceived rise in childhood violence.

\section{METHODS}

Data regarding television viewing habits, and the amount of violence on British television, were obtained from Ofcom $^{13}$ (formerly the Broadcasting Standards Commission). For comparison, the currently most popular audio compilation of nursery rhymes, as ordered from amazon.co.uk (search term "nursery rhymes", 24 June 2003, sales rank 902) $)^{14}$ was used as the source of the 25 top rhymes. The words for the nursery rhymes were taken from internet databases. ${ }^{15-19}$ They were then independently scanned for evidence of violent episodes by the first three researchers. These episodes were subdivided into accidental, aggressive, and intentional categories, and included implied and threatened violence. 
Table 1 Nursery rhyme associated violence episodes

\begin{tabular}{|c|c|c|c|c|}
\hline \multirow[b]{2}{*}{ Nursery rhyme } & \multicolumn{4}{|c|}{ Episodes of violence } \\
\hline & Accidental & Aggressive & Intentional & Total \\
\hline Humpty Dumpty & 1 & 0 & 0 & 1 \\
\hline Baa-Baa Black Sheep & 0 & 0 & 0 & 0 \\
\hline This Old Man (Knick Knack Paddy Wack) & 0 & 0 & 0 & 0 \\
\hline Grand Olde Duke Of York & 0 & 1 & 0 & 1 \\
\hline Yankee Doodle & 0 & 0 & 0 & 0 \\
\hline How Much Is That Doggie In The Window & 0 & 1 & 0 & 1 \\
\hline Polly Put The Kettle On & 0 & 0 & 0 & 0 \\
\hline Here We Go Round The Mulberry Bush & 0 & 0 & 0 & 0 \\
\hline Ring-A-Ring-A-Roses & 0 & 0 & 0 & 0 \\
\hline Oranges And Lemons & 0 & 0 & 1 & 1 \\
\hline Simple Simon & 2 & 1 & 1 & 4 \\
\hline Pat-A-Cake Pat-A-Cake & 0 & 0 & 0 & 0 \\
\hline Rock-A-Bye Baby & 0 & 0 & 1 & 1 \\
\hline Twinkle Twinkle Little Star & 0 & 0 & 0 & 0 \\
\hline Muffin Man, The & 0 & 0 & 0 & 0 \\
\hline Hickory Dickory Dock & 1 & 0 & 0 & 1 \\
\hline Six $\ln$ a Bed & 0 & 0 & 5 & 5 \\
\hline Jack And Jill & 2 & 1 & 0 & 3 \\
\hline London Bridge Is Falling Down & 1 & 0 & 0 & 1 \\
\hline Little Miss Muffet & 0 & 0 & 0 & 0 \\
\hline Three Little Kittens & 0 & 0 & 0 & 0 \\
\hline Sing A Song Of Sixpence & 0 & 1 & 0 & 1 \\
\hline Cockles And Mussels & 0 & 0 & 0 & 0 \\
\hline Incy-Wincy Spider & 0 & 0 & 0 & 0 \\
\hline Here We Go Luby-Loo & 0 & 0 & 0 & 0 \\
\hline Total & 7 & 5 & 8 & 20 \\
\hline
\end{tabular}

The results from the three researchers were compared and where discrepancies arose, these were discussed and consensus was reached.

\begin{tabular}{lcll} 
Table 2 & Types of violent scene & & \\
\hline & Television & \multicolumn{2}{l}{ Nursery rhymes } \\
\cline { 3 - 4 } & $(\%)$ & No. & $\%$ \\
\hline Act only & 5 & 10 & 50 \\
Act and result & 61 & 6 & 30 \\
Results & 15 & 0 & 0 \\
Property damage & 11 & 1 & 5 \\
Verbal threat & 2 & 0 & 0 \\
Physical threat & 4 & 1 & 5 \\
Implied & 2 & 2 & 10 \\
Other & 0 & 0 & 0 \\
\hline
\end{tabular}

\begin{tabular}{lll}
\hline $\begin{array}{l}\text { Table } 3 \\
\text { viewing }\end{array}$ & Comparison of violence type with television \\
\hline Type of violence & Television (\%) & Nursery rhymes (\%) \\
\hline Accidental & 18 & 35 \\
Aggressive & 11 & 25 \\
Implied & 71 & 40 \\
\hline
\end{tabular}

The nursery rhymes were then recited, in turn, to the fourth researcher, and his response to them was noted. Nonverbal communication was the subject's preferred means of communication. A relatively limited repertoire of facial expressions allowed responses to be classified as positive (smiling, flapping arms, clapping hands), neutral (inattention, monotone babbling, nose picking, straining at stool), or negative (crawling away, crying). The time taken for the rhymes to be spoken was noted. Normal amounts of nonverbal embellishment of the rhymes to depict actions and scenes were used.

\section{RESULTS}

Ofcom's report, Depiction of violence on terrestrial television ${ }^{19}$ looked at levels of violence depicted on the five terrestrial television channels in 2001. Television was monitored between 1730 and 2400 . We only used data from the programmes before 2100 (when children are more likely to be watching). A total of 1045 violent scenes were shown over two weeks. The 25 nursery rhymes took 23 minutes to recite.

Table 1 lists nursery rhyme associated violence episodes. Table 2 lists the types of violent scene on television and in nursery rhymes. Table 3 compares violence type with television viewing and table 4 compares frequency of violent scenes.

Furthermore, four episodes of emotional distress to humans were identified. An episode of emotional distress to an animal (Little Miss Muffett) was discounted. Five episodes of law breaking were also found.

Table 4 Frequency of violent scenes

\begin{tabular}{lll}
\hline & Television & Nursery rhymes \\
\hline Proportion of programmes/rhymes with violence & $51 \%$ & $11 / 25(44 \%)$ \\
Number of scenes per hour of watching/listening & 4.8 & 52.2 \\
Length of viewing/listening needed for 1 violent episode & $12 \mathrm{~min} 30 \mathrm{sec}$ & $1 \mathrm{~min} 9 \mathrm{sec}$ \\
\hline
\end{tabular}


Statistical analysis was not performed as we had no access to the core data from the television group.

Analysis of responses of the fourth researcher to rhyme recital strongly suggested a pattern of behaviour unrelated to the content of the rhymes. Episodes of violence were greeted equally with positive, negative, or neutral responses. The presence of other small children, biscuits, and musical purple dinosaurs all appeared to confound response by their external influences.

\section{DISCUSSION}

Our results show that a significant amount of violence permeates childhood, both with traditional and with newer methods of child entertainment. Similar numbers of television programmes and nursery rhymes contain violent episodes ( $51 \%$ versus $45 \%$ ), but we have shown these to be different in type, in pattern, and in frequency per hour.

The effect of witnessing or imagining a violent episode on a child may be dependent on its type and graphical nature. Although nursery rhymes are a non-visual medium, artists and film makers have long been aware that the imagined can be more powerful than the graphic. A good example of this is the horror film Night of the Living Dead Part 2, whose over reliance on graphic scenes make it much less frightening than the disturbing implied horror of The Wicker Man.

Television is twice as likely to show or mention the result of the violence compared to the nursery rhymes. This allows the child, having heard a rhyme, to make their own image and conclusion of the effects and outcome of the episode. At times this may be more disturbing than having the outcome spelled out, as children often over interpret the results of such acts. That noises in the dark are caused by the resident monster under the bed is well known to any child, but adults are more likely to blame passing wind or other natural phenomena.

Emotional distress was not analysed in Ofcom's report, but we identified four further rhymes which involved significant levels of distress to a character. We believe this could be just as damaging to certain children as the violence episodes.

Neither our study nor the Ofcom's results was able to evaluate the severity of the episodes of violence. For instance, "Here comes the chopper to chop off your head" (Oranges and Lemons), or a blackbird pecking off someone's nose (Sing a Song of Sixpence) probably has a different impact level to someone falling out of a bed (Six in a Bed).

The effects of the violence of nursery rhymes may also be moderated by the person telling them, which is not possible with television. This may however work to augment the nature of the episode, where a seemingly innocuous event can be built in to a significant episode of violence. For instance, "The clock struck one" in Hickory Dickory Dock can be interpreted to signify the striking of a mouse instead of the time signal, and the imagery of death in Ring a Ring of Roses would be apparent to a child only after adult explanation.

Other episodes which caused concern, for instance placing a baby intentionally in harm's way by placing his or her cot in a tree top, may also cause distress to a child's perception of its safety. A social services referral would undoubtedly follow.

When analysed for episodes per hour, the frequency of violence with nursery rhymes is around 11 times that with television viewing. It could therefore be argued that placing a young child in front of a television before $9 \mathrm{pm}$ could reduce their exposure to violence. Interpretation of the effects of this style of child rearing on other important social factors, for instance communication and play skills, is beyond the scope of this study.
Our study indicates that young children have been exposed to violent episodes long before the advent of television. Although we do not advocate exposure for anyone to violent scenes or stimuli, childhood violence is not a new phenomenon. The writings of Dickens and Shakespeare both make frequent references to childhood offenders. The development of the violent child and individual is multi-factorial, involving many socioeconomic and educational factors. Reinterpretation of an ancient problem through modern eyes is difficult, and laying the blame solely on television viewing is simplistic and may divert attention from vastly more complex societal problems. Socrates said in 425 BC: "If the whole world depends on today's youth, I can't see the world lasting another 100 years". Maybe whatever we do, the "youth of today" will grow up to be just like us!

\section{Authors' affiliations}

P Davies, Emergency Department, Bristol Royal Hospital for Children, Bristol, UK

L Lee, Neonatal Intensive Care Unit, St Michael's Hospital, Bristol, UK A Fox, Dept of Paediatric Allergy, St Mary's Hospital, London, UK

E Fox, Little Gems Nursery, London Rd, Stanmore, Middlesex, UK

Conflict of interest: AF is related to $E F$. EF is only allowed to watch half an hour of television per day (exclusively pre-watershed). PD and LL were due their first baby in November. They hope to bring him or her up appropriately.

Local ethics approval was granted by Mrs T Fox.

\section{REFERENCES}

1 Smith S, Allen J. Violent crime in England and Wales, Home Office online report 18/04.www.homeoffice.gov.uk/rds/pdfs04/rdsolr1804.pdf (accessed 17 June 2004).

2 East K, Campbell S. Aspects of crime. Young Offenders 1999, Home Office. www.homeoffice.gov.uk/rds/pdfs/aspects-youngoffs.pdf (accessed 17 June 2004).

3 Scottish Executive. Incidents of violence and anti-social behaviour against local authority school staff in 2002/03, www.scotland.gov.uk/stats/bulletins/ 00318-00.asp (accessed 17 June 2004).

4 Scottish Executive. Incidents of violence against local authority school staff in 2000-2001, http://www.scotland.gov.uk/stats/bulletins/00140-00.asp (accessed 17 June 2004).

5 Scottish Executive. Incidents of violence and anti-social behaviour against local authority school staff in 2001/02, http://www.scotland.gov.uk/stats/ bulletins/00230-00.asp (accessed 17 June 2004).

6 Surgeon General's Scientific Advisory Committee on Television and Social Behavior. Television and growing up: the impact of televised violence. Washington, DC: US Government Printing Office, 1972.

7 Johnson JG, Cohen P, Smailes EM, et al. Television viewing and aggressive behavior during adolescence and adulthood. Science 2002;295:2468-71.

8 Anderson CA, Bushman BJ. The effects of media violence on society. Science 2002;295:2377-9.

9 Shifrin D. Three-year study documents nature of television violence. AAP news August 1998, www.aap.org/advocacy/shifrin898.htm (accessed 17 June 2004).

10 DuRant R, Borgerding E, Smith K. Viewing wrestling on television, dating violence, and engaging in health risk behaviours by adolescents. Pediatr Res 2001;49:123A.

11 Rowling JK. Harry Potter and the Order of the Phoenix, ISBN 0747551006.

12 Giles S, Shea S. Head injuries in nursery rhymes: evidence of a dangerous subtext in children's literature. CMAJ 2003;169:1294-6.

13 Ofcom. Riverside House, 2a Southwark Bridge Road, London SE1 9HA. www.ofcom.org.uk (accessed 17 June 2004).

14 Anon. Nursery rhyme favourites, ASIN B00002DGDL, www.amazon.co.uk/ exec/obidos/ASIN/B00002DGDL/qid $=1087462840 / \mathrm{sr}=2-2$ / ref=sr_2_11_2/202-0119101-0394268 (accessed 17 June 2004).

15 www.collingsm.freeserve.co.uk/ (accessed 17 June 2004).

16 www.singingbabies.com/lyrics.html (accessed 17 June 2004)

17 www.momsview.com/nursery.html (accessed 17 June 2004).

18 www.zelo.com/family/nursery/index.asp (accessed 17 June 2004).

19 Broadcasting Standards Commission. The depiction of violence on terrestrial television, Broadcasting Standards Commission, 7 The Sanctuary, London SWIP 3JS.www.ofcom.org.uk/research/consumer_audience_research/tv/ tv_audience_reports/depiction_of_violence_on_tv.pdf (accessed 17 June 2004). 